Check for updates

Cite this: RSC Adv., 2019, 9, 31370

\title{
Kinetics and pathways of diclofenac degradation by heat-activated persulfate
}

\author{
Hongle Shi, Gaofeng Zhou, Yiqing Liu, (D) * Yongsheng Fu, Hongbin Wang \\ and Peng Wu
}

In this study, the degradation of diclofenac (DCF) by heat-activated persulfate (HAP) was investigated. It was found that DCF could be degraded efficiently by HAP. The degradation of DCF followed the pseudo-firstorder kinetic model, and the highest observed degradation rate constant $\left(k_{\text {obs }}\right)$ was obtained at $\mathrm{pH} 3$. The sulfate radical was mainly responsible for $\mathrm{DCF}$ removal at $\mathrm{pH}<7$, whereas it was the hydroxyl radical at high $\mathrm{pH}$. The elimination of DCF was enhanced with the increase in temperature or initial dosage of persulfate. Presence of $\mathrm{Cu}^{2+}$ and $\mathrm{CO}_{3}{ }^{2-}$ could improve DCF degradation, while an inhibition effect was observed in the presence of natural organic matter. According to the identified nine transformation products, the potential DCF degradation mechanism was proposed revealing five different reaction pathways, including hydroxylation, decarboxylation, formylation, dehydrogenation and $\mathrm{C}-\mathrm{N}$ bond cleavage. This study indicates that HAP can effectively oxidize and degrade DCF, especially under acidic conditions.

Received 3rd July 2019

Accepted 23rd September 2019

DOI: $10.1039 / c 9 r a 05034 \mathrm{e}$

rsc.li/rsc-advances

\section{Introduction}

Huge amounts of pharmaceuticals are used every year by humans throughout the world. ${ }^{1,2}$ For example, 836 tons acetylsalicylic acid, 622 tons paracetamol, 345 tons ibuprofen and 86 tons diclofenac were used in Germany in $2001 .^{3}$ Diclofenac (DCF), a widely used non-steroidal anti-inflammatory drug, was frequently detected in groundwater, treated sewage and surface water in recent years. ${ }^{4,5}$ It could hardly be removed completely by the conventional wastewater treatment plants. Thus, the effluent of raw and treated sewage was considered to be its primarily pathway entering the environment. ${ }^{6,7}$ Oaks et al. ${ }^{8}$ reported that DCF could cause a high death rate among three species of vulture in India and Pakistan. The biological toxicity of DCF may also induce a risk to the other organisms or even human health. As a result, its risk should be paid urgent attention though its concentration in the natural environment is very low.

Advanced oxidation processes (AOPs) have received significant attention for the degradation of emerging contaminants in recent years. ${ }^{9-11}$ AOPs are characterized by the production of active radicals, such as hydroxyl radical ( $\left.\mathrm{HO}^{\circ}\right)$, sulfate radical $\left(\mathrm{SO}_{4}{ }^{-}\right)$and carbonate radical $\left(\mathrm{CO}_{3}{ }^{--}\right)$, which are very reactive and even can mineralize organic pollutants thoroughly. Hydroxyl radical-based AOPs $\left(E^{0}=2.8 \mathrm{~V}\right)$, including Fenton, photo-Fenton, $\mathrm{UV} / \mathrm{H}_{2} \mathrm{O}_{2}$ and $\mathrm{O}_{3} / \mathrm{H}_{2} \mathrm{O}_{2}$, are widely investigated in last decades. ${ }^{11-13}$ Recently, considerable papers about the

Faculty of Geosciences and Environmental Engineering, Southwest Jiaotong University, Chengdu 611756, China. E-mail: liuyq@swjtu.edu.cn degradation of DCF by hydroxyl radical-based AOPs were reported, such as $\mathrm{UV} / \mathrm{H}_{2} \mathrm{O}_{2},{ }^{12}$ photo-Fenton, ${ }^{14} \mathrm{UV} / \mathrm{TiO}_{2},{ }^{15}$ etc. In addition, sulfate radical $\left(E^{0}=2.5-3.1 \mathrm{~V}\right)$ and carbonate radical $\left(E^{0}=1.78 \mathrm{~V}\right.$ at $\left.\mathrm{pH} 7\right)$ also drew public attention because of their selectivity and high oxidation capability.,16,17 Particularly, sulfate radical (SR)-based AOPs have caused more attention, because $\mathrm{SO}_{4}{ }^{--}$can be readily generated through transition metal, UV or heat activation of cheap oxidants (e.g., persulfate (PS) and peroxymonosulfate (PMS)) and these technologies have achieved success in the elimination of many emerging contaminants. Of which heat-activated persulfate (HAP) is a relatively green SR-AOPs which will not bring secondary pollution though it needs energy input. Therefore, HAP has been widely studied to degrade amounts of organic compounds such as duron, ${ }^{18}$ carbamazepine, ${ }^{19} p$-nitrophenol, ${ }^{20}$ benzoic acid, ${ }^{21}$ triclosan $^{22}$ and so on. The degradation of DCF by HAP was also investigated by Chen et al. ${ }^{23}$ but its reaction mechanism in this system is still unclear until now. Besides, although the influence of several water matrix $\left(\right.$ e.g., $\mathrm{Cl}^{-}, \mathrm{HCO}_{3}{ }^{-}$, and natural organic matter (NOM)) on DCF removal were explored in their study, the effect of the other constituents such as $\mathrm{CO}_{3}{ }^{2-}$, $\mathrm{SO}_{4}{ }^{2-}, \mathrm{NO}_{3}{ }^{-}, \mathrm{Fe}^{3+}$, and $\mathrm{Cu}^{2+}$ were not investigated. Accordingly, the removal of DCF by HAP was systematically investigated in this study including degradation kinetics, influence factors and transformation mechanism.

The main objectives of this work were: (i) to investigate the effect of common water matrix including metal cations (e.g., $\mathrm{Fe}^{3+}$ and $\mathrm{Cu}^{2+}$ ), inorganic anions (i.e., $\mathrm{CO}_{3}{ }^{2-}, \mathrm{SO}_{4}{ }^{2-}$ and $\mathrm{NO}_{3}{ }^{-}$) and NOM on DCF degradation; (ii) to detect the transformation products of DCF for speculating its degradation mechanism by 
HAP; and (iii) to identify the dominant reactive radical species and quantify their contribution to DCF removal in HAP system at different $\mathrm{pH}$ values through the radical scavenging experiments based on the fact that the radical species is dependent on the solution $\mathrm{pH}$ in SR-AOPs.

\section{Materials and methods}

\subsection{Materials}

Diclofenac sodium (99\%) was obtained from Aladdin (China). Methanol, acetic acid, isopropanol and tert-butanol were all HPLC grade and purchased from Kelong (Chengdu, China). All the other reagents were AR grade and used without further purification. Milli-Q water (18 $\mathrm{M} \Omega \mathrm{cm})$ was used for preparing all aqueous solutions.

\subsection{Experimental setup}

All experiments were carried out in a $1 \mathrm{~L}$ glass beaker containing $600 \mathrm{~mL}$ reaction solution. Before adding DCF and the other chemicals, the reactor was pre-heated in a thermostat water bath for about $30 \mathrm{~min}$ to reach to the desired temperature. Then, DCF standard solution was added into the reaction solution and its initial concentration was $1 \mu \mathrm{M}$. After that, the solution was stirred rapidly for several minutes by a mechanical agitator, ensuring a complete mixing of solution. Finally, appropriate volume of $6 \mathrm{mM}$ persulfate was added into the solution, and the reaction began. At given time intervals, $1.5 \mathrm{~mL}$ reaction solution was sampled and fleetly quenched with $0.45 \mathrm{M}$ $\mathrm{Na}_{2} \mathrm{~S}_{2} \mathrm{O}_{3}$. All the experiments were conducted in triplicate. The error bars in the figures represent the standard error of the mean.

\subsection{Chemical analysis}

The concentration of DCF was determined by a high performance liquid chromatograph (HPLC, Waters 2695, USA) equipped with a symmetry C18 column $(5 \mu \mathrm{m}, 4.6 \times 150 \mathrm{~mm})$ and a UV detector (Waters 2966, USA) at $276 \mathrm{~nm}$. The mobile phase consisted of methanol and $1 \%$ acetic acid water solution

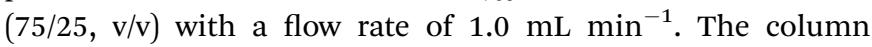
temperature was $30^{\circ} \mathrm{C}$ and the sample injection volume was 20 $\mu \mathrm{L}$. pH was measured by a pH meter (INESA Scientific Instrument Co., Ltd, China). The transformation products of DCF were detected using an ultra performance liquid chromatograph coupled with a quadrupole-time of flight-mass spectrometry (UPLC-QTOF/MS, Waters Xevo G2-XS QT, USA). The chromatographic separation was performed on a C18 column $(1.7 \mu \mathrm{m}, 2.1 \times 100 \mathrm{~mm})$ with the sample injection volume of 10 $\mu \mathrm{L}$. The mobile phase contained A $(0.1 \%$ formic acid in water $)$ and $\mathrm{B}$ (acetonitrile) at the flow rate of $0.3 \mathrm{~mL} \mathrm{~min}{ }^{-1}$. The gradient was $10 \% \mathrm{~B}$ in the initial $0.5 \mathrm{~min}$, linearly increasing to $100 \%$ B for $6.5 \mathrm{~min}$, and decreasing back to $10 \%$ B for $3 \mathrm{~min}$. The mass spectrum $(\mathrm{m} / \mathrm{z} 50-800)$ was analyzed in a positive ion mode by electrospray ionization (ESI) with the drying gas temperature of $400{ }^{\circ} \mathrm{C}$ and capillary voltage of $2.5 \mathrm{kV}$. Data were analyzed through Masslynx 4.1 software (Waters, USA).

\section{Results and discussion}

\subsection{Degradation of DCF by HAP}

Fig. 1 shows the degradation of DCF by heat alone, PS alone and HAP. DCF was hardly degraded after $60 \mathrm{~min}$ by heat alone and PS alone, while about $96 \%$ DCF was removed after 30 min with the addition of persulfate at $70{ }^{\circ} \mathrm{C}$ which was probably due to the role of the formed radicals from the activated PS by heat. The degradation of DCF in HAP system followed a pseudo-firstorder kinetic model, and the observed degradation rate constant was thus calculated to be $0.103 \mathrm{~min}^{-1}$ according to eqn (1).

$$
-\mathrm{d}[\mathrm{DCF}] / \mathrm{d} t=k_{\mathrm{obs}}[\mathrm{DCF}]
$$

where $k_{\text {obs }}$ is the pseudo-first-order rate constant of DCF by HAP, and $[\mathrm{DCF}]$ is the molar concentration of DCF at any time.

\subsection{Effect of initial $\mathrm{pH}$}

The solution $\mathrm{pH}$ can affect the species and concentration of active radicals (i.e., $\mathrm{HO}^{\circ}$ and $\mathrm{SO}_{4}{ }^{-{ }^{-}}$) in SR-AOPs, which may influence the degradation of organic contaminants. ${ }^{24,25}$ The effect of $\mathrm{pH}(3.0-$ 11.0) on DCF degradation is shown in Fig. 2. The removal rate of DCF at $\mathrm{pH} 3\left(k_{\mathrm{obs}}=0.48 \mathrm{~min}^{-1}\right)$ was remarkably higher than those at the other $\mathrm{pH}$ values. At the strong acid condition, Caro's acid $\left(\mathrm{H}_{2} \mathrm{SO}_{5}\right)$ might be formed, as shown in eqn (2), and its redox potential was reported to be $1.50 \mathrm{~V} \cdot{ }^{26,27}$ To clarify if DCF could be oxidized by the formed $\mathrm{H}_{2} \mathrm{SO}_{5}$, the removal of DCF in the presence of persulfate under the room temperature $\left(25^{\circ} \mathrm{C}\right)$ at $\mathrm{pH} 3$ was investigated. As shown in Fig. 2, DCF could hardly be degraded in this reaction condition, indicating that it could not be removed by $\mathrm{H}_{2} \mathrm{SO}_{5}$ oxidation. Therefore, the fastest DCF degradation at $\mathrm{pH} 3$ might be ascribed to the increase in the steady-state concentration of reactive radicals in this system, because the structure of Caro's acid was similar to that of peroxymonosulfate, leading to its possible activation by heat to produce $\mathrm{HO}^{\circ}$ and $\mathrm{SO}_{4}{ }^{-{ }^{-}}$, as presented in eqn (3). ${ }^{28}$ To verify the above speculation, two different alcohols,

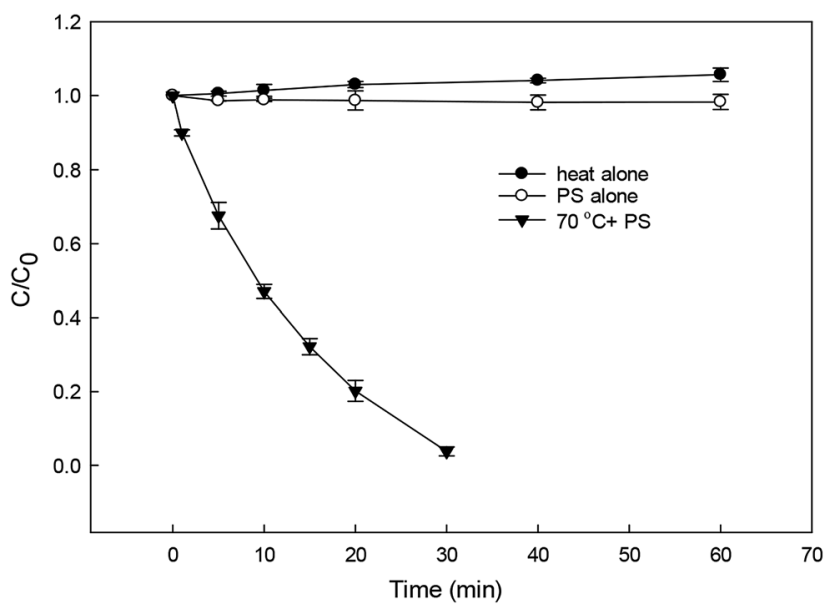

Fig. 1 Degradation of DCF by different reaction systems. Experimental conditions: $[\mathrm{DCF}]_{0}=1 \mu \mathrm{M}$. [PS $]_{0}=50 \mu \mathrm{M}$, no buffer, $T=25^{\circ} \mathrm{C}$ for PS alone system, $T=70^{\circ} \mathrm{C}$ for heat alone and HAP systems. 


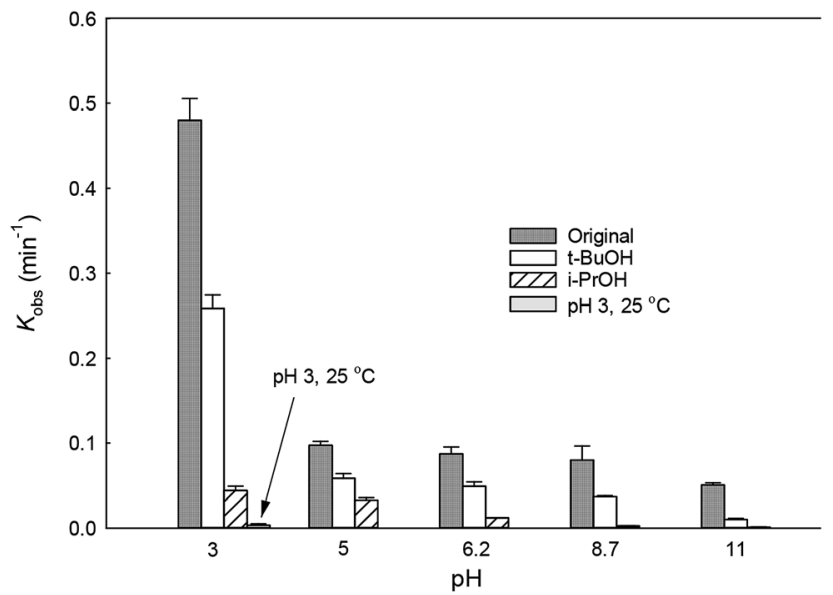

Fig. 2 Variation of $k_{\text {obs }}$ as a function of initial $\mathrm{pH}$ for DCF degradation. Experimental conditions: $[\mathrm{DCF}]_{0}=1 \mu \mathrm{M},[\mathrm{PS}]_{0}=50 \mu \mathrm{M},[t-\mathrm{BuOH}]_{0}=[\mathrm{i}-$ $\mathrm{PrOH}]_{0}=5 \mathrm{mM}, T=70^{\circ} \mathrm{C}\left(T=25^{\circ} \mathrm{C}\right.$ for verifying group at $\left.\mathrm{pH} 3\right), 5 \mathrm{mM}$ phosphate buffer.

i.e., tert-butanol $\left(t-\mathrm{BuOH}, k_{\mathrm{SO}_{4}{ }^{-} / t-\mathrm{BuOH}}=(4-9.1) \times 10^{5} \mathrm{M}^{-1} \mathrm{~s}^{-1}\right.$, $\left.k_{\mathrm{HO} / t-\mathrm{BuOH}}=(4.2-7.6) \times 10^{8} \mathrm{M}^{-1} \mathrm{~s}^{-1}\right)$ and isopropanol (i-PrOH,

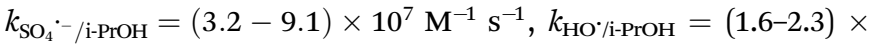
$10^{9} \mathrm{M}^{-1} \mathrm{~s}^{-1}$ ), were added into this system, respectively. ${ }^{29-31}$ As shown in Fig. 2, due to the scavenging of $t-\mathrm{BuOH}$ for $\mathrm{HO}^{*}$, the degradation of DCF at $\mathrm{pH} 3$ was inhibited significantly with its addition. While the inhibition effect was more obvious in the presence of $\mathrm{i}-\mathrm{PrOH}$, because it could also react with $\mathrm{SO}_{4}{ }^{-}$except quenching $\mathrm{HO}^{\circ}$. This radical scavenging experiment indicated that $\mathrm{SO}_{4}{ }^{--}$and $\mathrm{HO}^{\circ}$ were both present and responsible for DCF removal by HAP at $\mathrm{pH} 3$ and their contribution to DCF degradation were $54 \%$ and $46 \%$, respectively.

$$
\begin{gathered}
\mathrm{S}_{2} \mathrm{O}_{8}{ }^{2-}+\mathrm{H}^{+}+\mathrm{H}_{2} \mathrm{O} \rightarrow \mathrm{H}_{2} \mathrm{SO}_{5}+\mathrm{HSO}_{4}{ }^{-} \\
\mathrm{HSO}_{5}{ }^{-} \stackrel{\text { heat }}{\longrightarrow} \mathrm{SO}_{4}{ }^{--}+\mathrm{HO} \cdot
\end{gathered}
$$

With the increase of initial pH from 5 to 11 , the concentration of $\mathrm{OH}^{-}$in the solution increased gradually. It could react with $\mathrm{SO}_{4}{ }^{--}$, as presented in eqn (4), lowering the contribution of this radical to DCF removal, ${ }^{32}$ which was also confirmed by the radical scavenging experiments where the contribution of $\mathrm{SO}_{4}{ }^{-}$ to DCF degradation were $60.4 \%, 56.4 \%, 46.2 \%$ and $20.1 \%$ at $\mathrm{pH}$ 5, 6.2, 8.7 and 11, respectively, as described in Fig. 2 and Table 1. Although $\mathrm{HO}^{\circ}$ could be formed from the above reaction, it could also be scavenged by $\mathrm{OH}^{-}$and $\mathrm{SO}_{4}{ }^{-}$, as shown in eqn (5)

Table 1 Contribution of reactive radical species to DCF degradation in HAP system at different $\mathrm{pH}$ values

\begin{tabular}{llll}
\hline $\mathrm{pH}$ & $k_{\mathrm{obs}}\left(\mathrm{min}^{-1}\right)$ & $\mathrm{SO}_{4}{ }^{-}(\%)$ & $\mathrm{HO}(\%)$ \\
\hline 3 & 0.480 & 54 & 46 \\
5 & 0.097 & 60.4 & 39.6 \\
6.2 & 0.087 & 56.4 & 43.6 \\
8.7 & 0.080 & 46.2 & 53.8 \\
11 & 0.050 & 20.1 & 79.9
\end{tabular}

and (6). ${ }^{32}$ Hence, the degradation rate of DCF declined from 0.097 to $0.050 \mathrm{~min}^{-1}$ when the initial $\mathrm{pH}$ changed from 5 to 11 . According to these results, we could conclude that except $\mathrm{pH} 3$, $\mathrm{SO}_{4}{ }^{-}-$was the dominant radical species at $\mathrm{pH}<7$; while $\mathrm{HO}{ }^{\circ}$ became the main radical at high $\mathrm{pH}$ condition in HAP system. Similar conclusion was also obtained by Tan et al. ${ }^{33}$ Overall, HAP was considered to be an efficient treatment technology for the degradation of DCF because of its effectiveness in a broad range of $\mathrm{pH}$, especially at $\mathrm{pH} \leq 3$.

$$
\begin{gathered}
\mathrm{SO}_{4}{ }^{--}+\mathrm{OH}^{-} \rightarrow \mathrm{SO}_{4}^{2-}+\mathrm{HO}^{\bullet} k=7.3 \times 10^{7} \mathrm{M}^{-1} \mathrm{~s}^{-1} \\
\mathrm{HO}+\mathrm{OH}^{-} \rightarrow \mathrm{O}^{--}+\mathrm{H}_{2} \mathrm{O} k=1.2 \times 10^{10} \mathrm{M}^{-1} \mathrm{~s}^{-1} \\
\mathrm{SO}_{4}^{{ }^{-}}+\mathrm{HO}^{\cdot} \rightarrow \mathrm{HSO}_{4}^{-}+0.5 \mathrm{O}_{2} k=1.2 \times 10^{9} \mathrm{M}^{-1} \mathrm{~s}^{-1}
\end{gathered}
$$

\subsection{Effect of reaction temperature}

The effect of temperature on DCF degradation in a range of 30$80{ }^{\circ} \mathrm{C}$ is shown in Fig. 3. When the reaction temperature was $30{ }^{\circ} \mathrm{C}$ and $40{ }^{\circ} \mathrm{C}$, DCF could hardly be degraded. As the temperature increased, the persulfate could gradually be activated readily to produce $\mathrm{SO}_{4}{ }^{-}$- leading to the enhancement of its steady-state concentration. Meanwhile, the collision probability between DCF and the reactive radicals might be improved with the increasing temperature based on the thermodynamics principle. $^{34}$ Therefore, the $k_{\text {obs }}$ increased from 0.007 to $0.207 \mathrm{~min}^{-1}$ when the temperature changed from 50 to $80{ }^{\circ} \mathrm{C}$. Most of the published papers on HAP system all found that the degradation of organic contaminant was faster in the higher temperature. ${ }^{33,35,36}$

The plot of $\ln k_{\text {obs }}$ vs. $1 / T$ (the insert in Fig. 3) showed an excellent fit with the Arrhenius type model (eqn (7)). The activation energy of DCF degradation by HAP was thus calculated to be $101.4 \mathrm{~kJ} \mathrm{~mol}^{-1}$ in this study. However, Chen et al. ${ }^{23}$ reported that the activation energy of this reaction was $157.63 \mathrm{~kJ} \mathrm{~mol}^{-1}$,

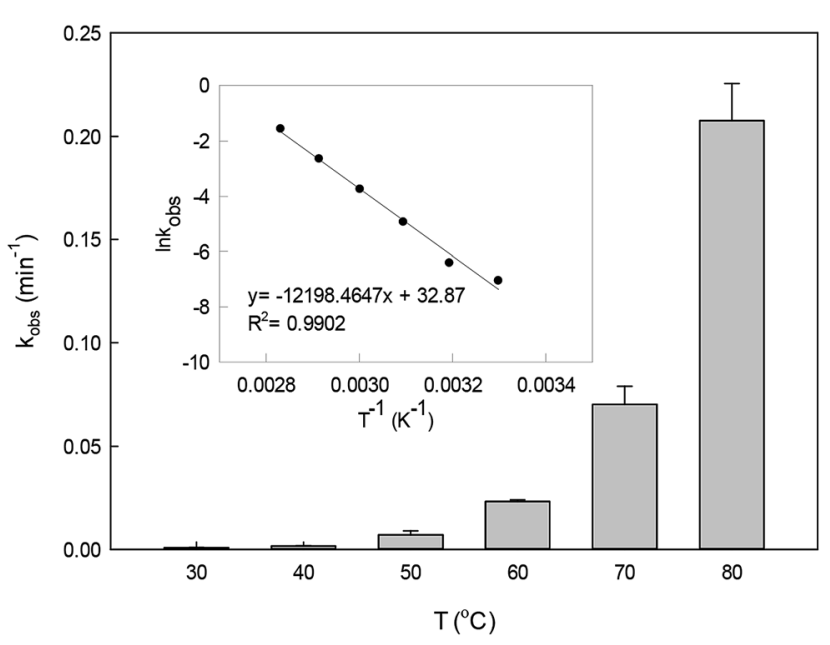

Fig. 3 Effect of temperature on $k_{\text {obs }}$ in HAP system. The inset is the Arrhenius plot for DCF degradation. Experimental conditions: $[\mathrm{DCF}]_{0}=$ $1 \mu \mathrm{M},[\mathrm{PS}]_{0}=50 \mu \mathrm{M}, 5 \mathrm{mM}$ phosphate buffer at $\mathrm{pH} 6.2$. 
which was higher than that obtained by this study. This disagreement might be due to the difference of the reaction conditions between their study $(\mathrm{pH}=7)$ and ours $(\mathrm{pH}=6.2)$.

$$
\ln k_{\mathrm{obs}}=\ln A-\frac{E_{\mathrm{A}}}{R T}
$$

where $A$ is the pre-exponential factor, $E_{\mathrm{A}}$ is the apparent activation energy of the reaction, $R$ is the universal gas constant (8.314 $\mathrm{J} \mathrm{mol}^{-1} \mathrm{~K}^{-1}$ ), and $T$ is the absolute temperature.

\subsection{Effect of initial PS dosage}

The dosage of PS is an important parameter in SR-AOPs, which can influence the degradation of target pollutants. Many researches have found that within the definite range of PS concentration, the degradation of organic contaminants enhanced with the increase in its dosage. Similar result was also obtained in our study on DCF removal by HAP, as shown in Fig. 4. The degradation rate of DCF enhanced from 0.003 to $0.087 \mathrm{~min}^{-1}$ as the concentration of PS increased from 1 to 50 $\mu \mathrm{M}$. The increase of PS dosage could produce more active radicals in HAP system, leading to the improvement on DCF degradation.

\subsection{Effect of water matrix}

3.5.1 Effect of metal cations. The effect of $\mathrm{Fe}^{3+}$ and $\mathrm{Cu}^{2+}(0-$ $10 \mu \mathrm{M}$ ) on DCF degradation in HAP system at $70{ }^{\circ} \mathrm{C}$ was investigated. As shown in Fig. $5 \mathrm{a}, \mathrm{Fe}^{3+}$ was found to be no obvious impact on the degradation of DCF. Anipsitakis et al. ${ }^{37}$ also reported that the persulfate could not be activated by $\mathrm{Fe}(\mathrm{III})$. However, the addition of $\mathrm{Cu}^{2+}$ could significantly improve DCF degradation (Fig. 5b), which was in agreement with the results reported by Deng et al. ${ }^{19}$ and Zhang et al. ${ }^{\mathbf{2 0}}$ The improvement effect enhanced gradually with the increase of $\mathrm{Cu}^{2+}$ concentration. Possible explanations for this result include: (1) PS could be activated by $\mathrm{Cu}^{2+}$ to produce $\mathrm{SO}_{4}{ }^{-}$, as shown in eqn (8), increasing the steady-state concentration of $\mathrm{SO}_{4}{ }^{-}$in HAP system; ${ }^{38}$ (2) the formed $\mathrm{Cu}^{3+}$ possessed a high oxidation

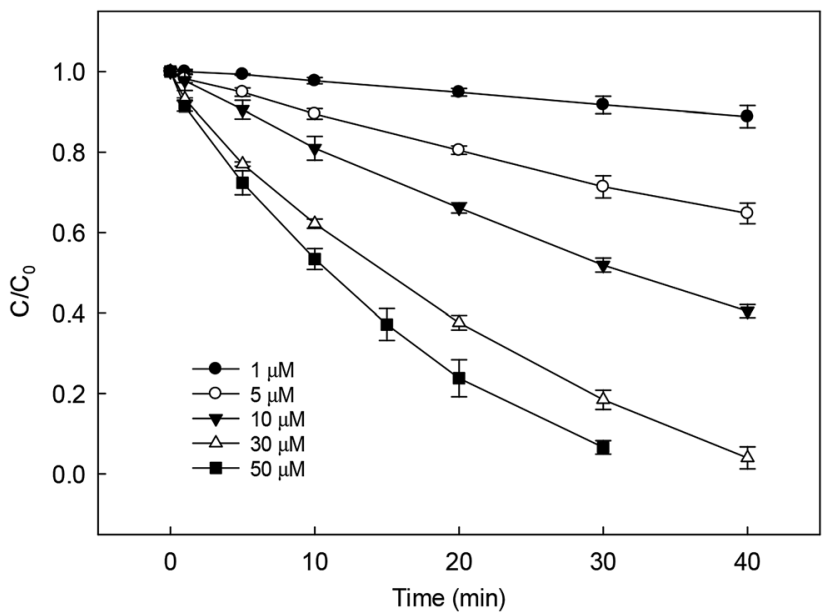

Fig. 4 Effect of initial PS dosage on DCF removal by HAP. Experimental conditions: $[D C F]_{0}=1 \mu \mathrm{M}, 5 \mathrm{mM}$ phosphate buffer at $\mathrm{pH}=6.2$.
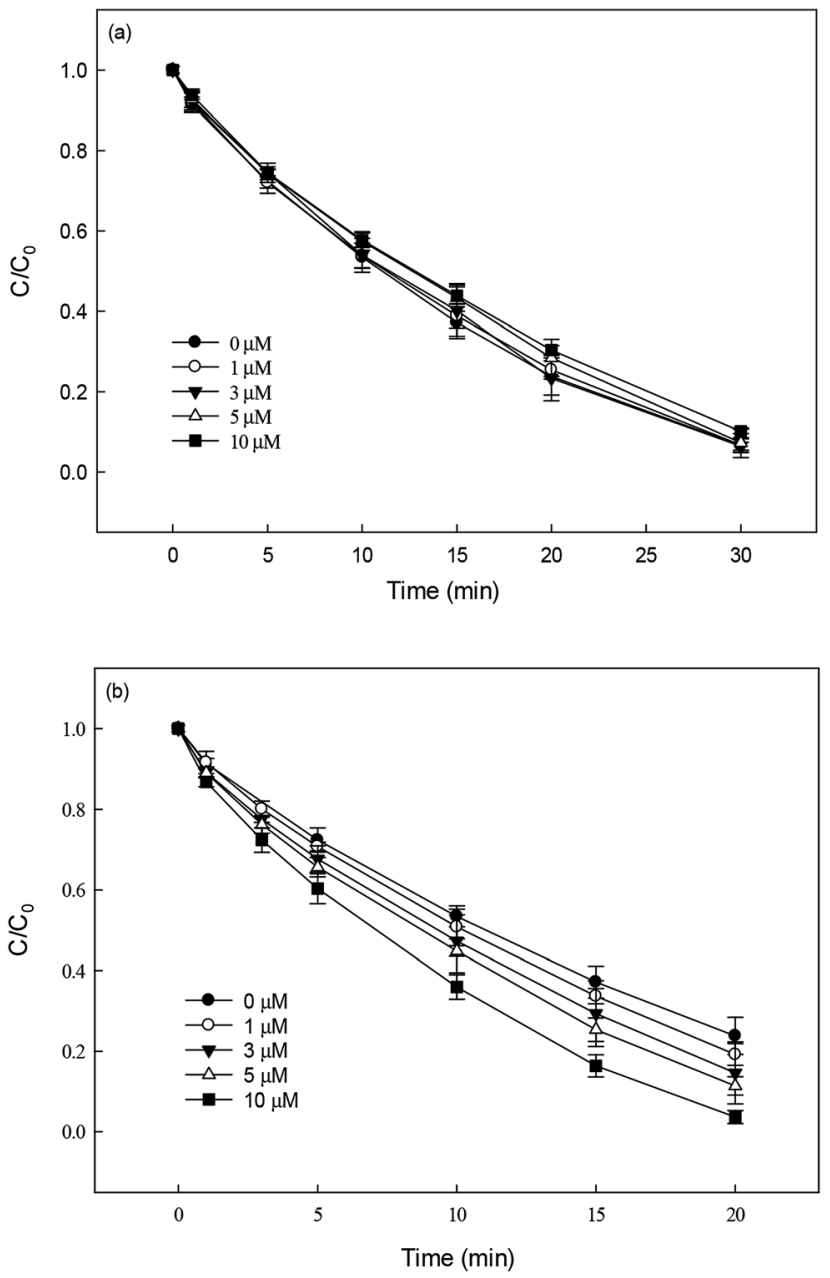

Fig. 5 Effect of $\mathrm{Fe}^{3+}$ (a) and $\mathrm{Cu}^{2+}$ (b) on DCF degradation in HAP system. Experimental conditions: $[\mathrm{DCF}]_{0}=1 \mu \mathrm{M},[\mathrm{PS}]_{0}=50 \mu \mathrm{M}, 5 \mathrm{mM}$ phosphate buffer at $\mathrm{pH} 6.2$.

capability and might be responsible for DCF degradation at a certain extent. ${ }^{19}$

$$
\mathrm{S}_{2} \mathrm{O}_{8}{ }^{2-}+\mathrm{Cu}^{2+} \rightarrow \mathrm{SO}_{4}{ }^{2-}+\mathrm{SO}_{4}{ }^{--}+\mathrm{Cu}^{3+}
$$

3.5.2 Effect of inorganic anions. Nitrate $\left(\mathrm{NO}_{3}{ }^{-}\right)$, sulfate $\left(\mathrm{SO}_{4}{ }^{2-}\right)$ and carbonate $\left(\mathrm{CO}_{3}{ }^{2-}\right)$ are common anions in natural water and may influence the degradation of target contaminant by SR-AOPs. Hence, their effect on DCF removal in HAP system was investigated, respectively. As shown in Fig. $6 a$ and b, the degradation of DCF could hardly be influenced in the presence of various concentrations of $\mathrm{NO}_{3}{ }^{-}$and $\mathrm{SO}_{4}{ }^{2-}$, because they can scarcely react with $\mathrm{SO}_{4}{ }^{--} \cdot{ }^{19} \mathrm{CO}_{3}{ }^{2-}$ is known to be an excellent scavenger for $\mathrm{HO}^{\circ}$ and $\mathrm{SO}_{4}{ }^{-}$, which may inhibit the removal of organic pollutants in AOPs. ${ }^{18,39}$ However, an enhancement effect on DCF degradation by HAP was observed in our study, as presented in Fig. $6 \mathrm{c}$. The presence of $\mathrm{CO}_{3}{ }^{2-}$ could change the $\mathrm{pH}$ of the solution, and reached 10.3, 10.6 and 10.8 when the concentration of carbonate was 1,3 and $5 \mathrm{mM}$, respectively. To avoid the influence of $\mathrm{pH}$ on DCF removal, the degradation of 

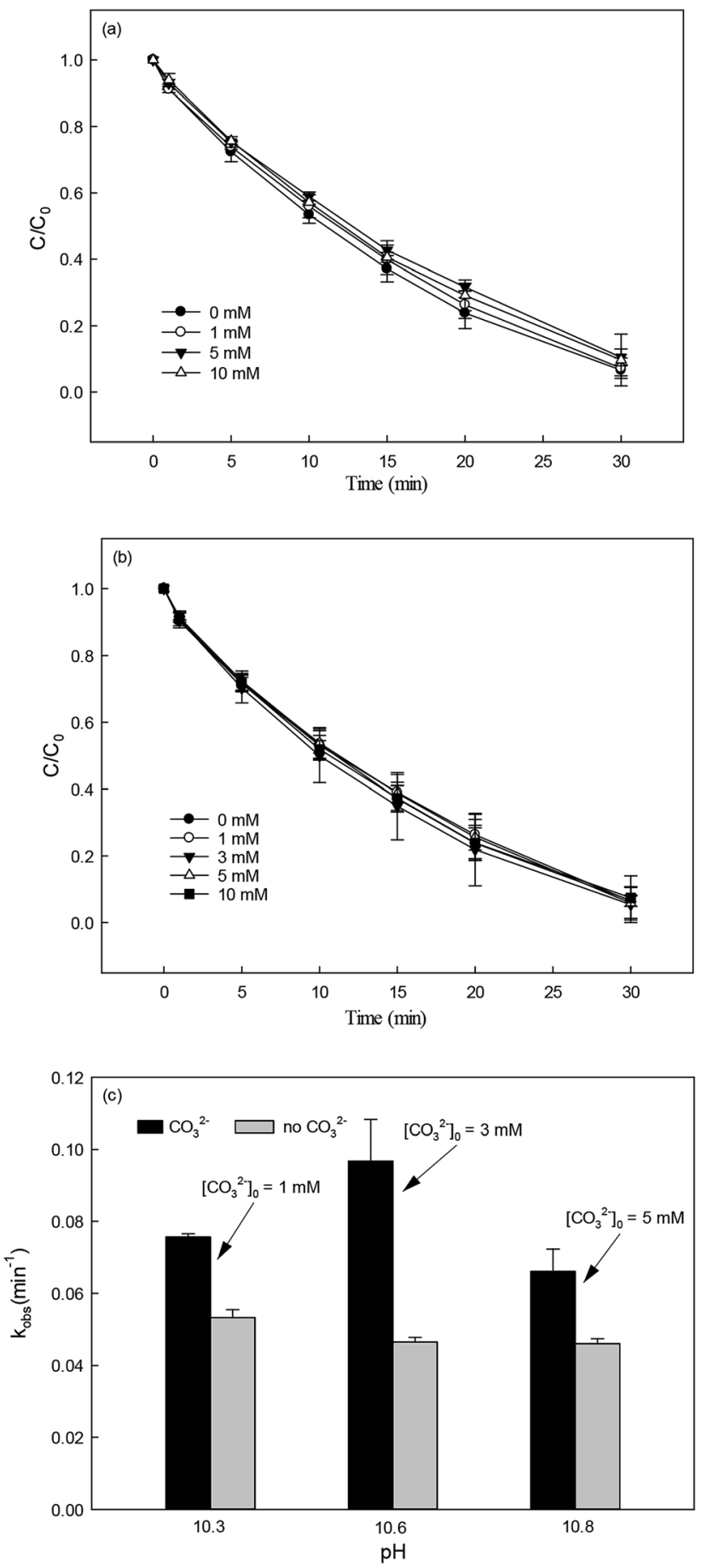

Fig. 6 Effect of $\mathrm{NO}_{3}{ }^{-}$(a), $\mathrm{SO}_{4}{ }^{2-}$ (b) and $\mathrm{CO}_{3}{ }^{2-}$ (c) on DCF degradation in HAP system. Experimental conditions: $[\mathrm{DCF}]_{0}=1 \mu \mathrm{M},[\mathrm{PS}]_{0}=50 \mu \mathrm{M}$, $5 \mathrm{mM}$ phosphate buffer at $\mathrm{pH}=6.2$ for $\mathrm{NO}_{3}{ }^{-}$and $\mathrm{SO}_{4}{ }^{2-}$ groups, no buffer for $\mathrm{CO}_{3}{ }^{2-}$ group.

DCF by HAP at these $\mathrm{pH}$ values was conducted as a control system. Compared with the respective control system, the removal of DCF in the presence of $\mathrm{CO}_{3}{ }^{2-}$ was obviously improved, which was probably attributed to the role of carbonate radical $\left(\mathrm{CO}_{3}{ }^{-}\right)$formed through the reactions of $\mathrm{CO}_{3}{ }^{2-}$ with $\mathrm{SO}_{4}{ }^{--}$and $\mathrm{HO}^{\circ}$, as presented in eqn (9) and (10). ${ }^{\mathbf{4 0 , 4 1}}$
Although the second-order rate constant of DCF with $\mathrm{CO}_{3}{ }^{\cdot-}$ $\left(k_{\mathrm{CO}_{3}{ }^{-} / \mathrm{DCF}}=(2.7 \pm 0.7) \times 10^{7} \mathrm{M}^{-1} \mathrm{~s}^{-142}\right)$ was lower than those with $\mathrm{SO}_{4}{ }^{-}\left(k_{\mathrm{SO}_{4}}{ }^{-} / \mathrm{DCF}=(9.2 \pm 0.6) \times 10^{9} \mathrm{M}^{-1} \mathrm{~s}^{-143}\right)$ and $\mathrm{HO}^{\cdot}$ $\left(k_{\mathrm{HO} / \mathrm{DCF}}=(7.5 \pm 1.5) \times 10^{9} \mathrm{M}^{-1} \mathrm{~s}^{-111}\right)$, its steady-state concentration might be higher in the reaction system due to its selectivity, ${ }^{44}$ resulting in a positive effect of $\mathrm{CO}_{3}{ }^{2-}$ on DCF degradation. Similar finding was also reported by Huang et al. ${ }^{\mathbf{4 2}}$ in DCF degradation by $\mathrm{UV} / \mathrm{NO}_{3}{ }^{-}$in the presence of $\mathrm{HCO}_{3}{ }^{-}$.

$$
\begin{aligned}
\underset{\mathrm{SO}_{4}{ }^{--}}{\mathrm{s}^{-1}} \mathrm{CO}_{3}{ }^{2-} & \rightarrow \mathrm{SO}_{4}{ }^{2-}+\mathrm{CO}_{3}{ }^{--} k=(6.2 \pm 0.4) \times 10^{6} \mathrm{M}^{-1} \\
\mathrm{HO} & +\mathrm{CO}_{3}^{2-} \rightarrow \mathrm{OH}^{-}+\mathrm{CO}_{3}{ }^{--} k=3.9 \times 10^{8} \mathrm{M}^{-1} \mathrm{~s}^{-1}
\end{aligned}
$$

3.5.3 Effect of NOM. Natural organic matter is a common constituent in natural water. It can react with $\mathrm{SO}_{4}{ }^{-}$and $\mathrm{HO}^{\circ}$ due to its electron-rich moieties, resulting in an inhibition effect on the removal of target contaminant. ${ }^{25,45,46}$ In this study, humic acid (HA) and fulvic acid (FA) were chosen to represent NOM for investigating their effect on DCF degradation in HAP system. As shown in Fig. 7a and b, the presence of HA and FA
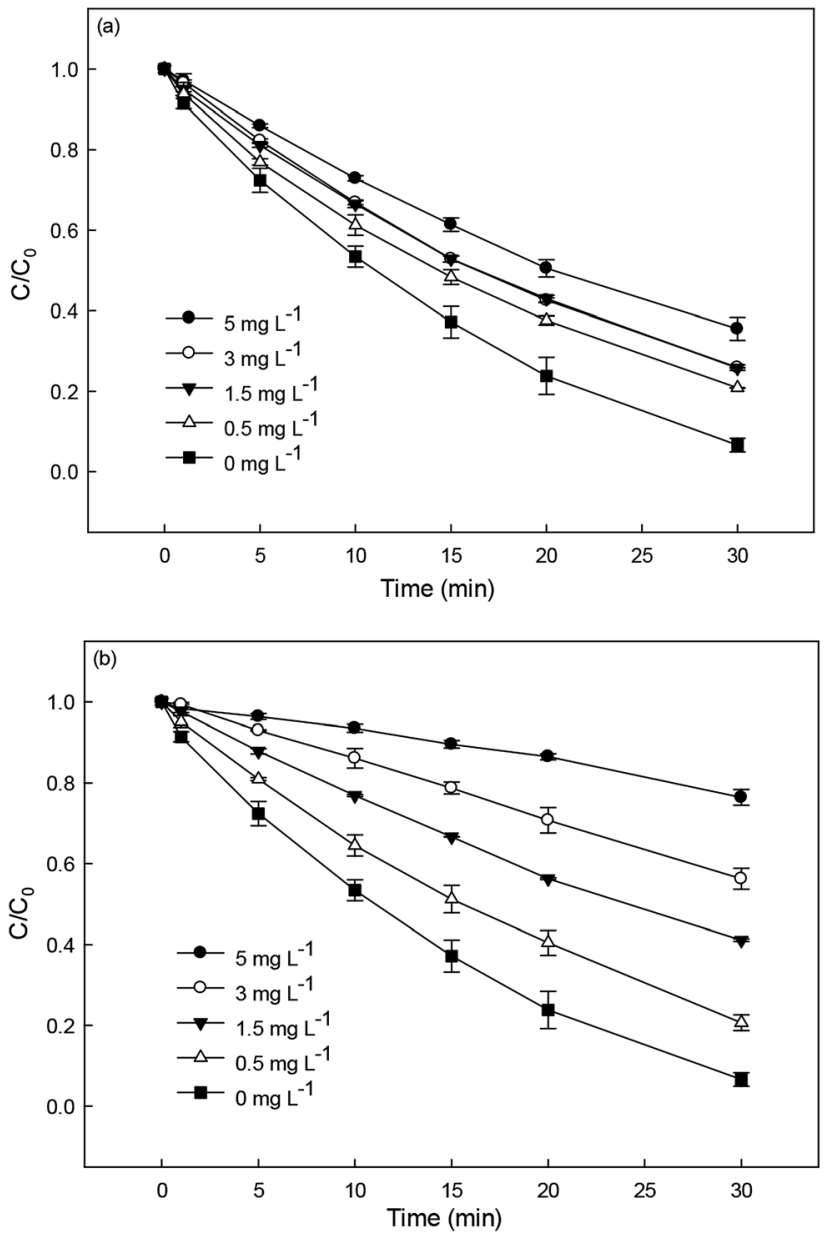

Fig. 7 Effect of HA (a) and FA (b) on DCF degradation in HAP system. Experimental conditions: $[\mathrm{DCF}]_{0}=1 \mu \mathrm{M},[\mathrm{PS}]_{0}=50 \mu \mathrm{M}, 5 \mathrm{mM}$ phosphate buffer at $\mathrm{pH}=6.2$. 
could both inhibit DCF degradation and the inhibition effect was more obvious with the increase of their concentrations. This was probably due to the competition of NOM with DCF for the reactive radicals. Compared with HA, the addition of FA showed a stronger inhibition on the degradation of DCF. However, it needs further investigation, because there is very limited available information on the reactivity of NOM toward $\mathrm{SO}_{4}{ }^{\cdot-}$.

\subsection{Degradation mechanism of DCF by HAP}

Nine transformation products (TPs) were detected during the degradation of DCF by HAP in this study. Based on these identified TPs, the potential DCF degradation mechanism was proposed, exhibiting five different transformation pathways including hydroxylation, decarboxylation, formylation, dehydrogenation and $\mathrm{C}-\mathrm{N}$ bone cleavage, as depicted in Scheme 1. (i) Hydroxylation (pathway (1) in Scheme 1) was an important pathway where DCF could be hydroxylated by the reactive radicals in HAP system. It is believed that $\mathrm{SO}_{4}{ }^{-{ }^{-}}$and $\mathrm{HO}^{\circ}$ have the similar reaction mechanisms, including hydrogen abstraction, hydroxyl addition and electron transfer. ${ }^{32,47}$ In terms of DCF structure, aromatic ring might be a target site which was easily attacked by $\mathrm{SO}_{4}{ }^{-}$- due to its electron-rich nature. Therefore, monohydroxylation product 5-hydroxy-DCF $(\mathrm{m} / \mathrm{z} 312)$ and dihydroxylation product $5,4^{\prime}$-hydroxy-DCF $(\mathrm{m} / \mathrm{z} 328)$ were produced.

(ii) Decarboxylation (pathway (2) in Scheme 1) meant an elimination of $-\mathrm{COOH}$ group from DCF structure. Phenylacetic acid structure on DCF might be attacked by $\mathrm{SO}_{4}{ }^{-}-$resulting in the transfer of an electron from aromatic ring to sulfate radical, and subsequently a - $\mathrm{COOH}$ group could be removed from this structure via intramolecular electron transfer producing<smiles>O=C(O)Cc1cc(O)ccc1Nc1c(Cl)cccc1Cl</smiles>

$\mathrm{m} / \mathrm{z} 312: \mathrm{C}_{14} \mathrm{H}_{11} \mathrm{NO}_{3} \mathrm{Cl}_{2}$

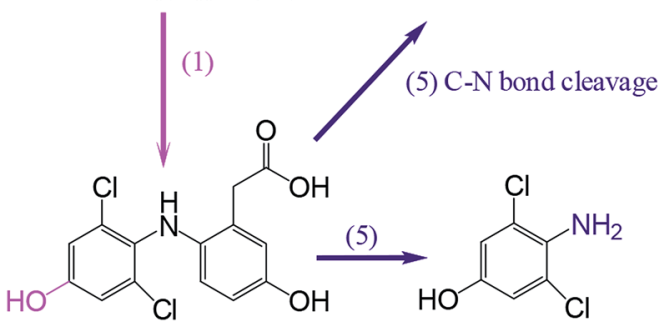

m/z 328: $\mathrm{C}_{14} \mathrm{H}_{11} \mathrm{NO}_{4} \mathrm{Cl}_{2} \quad$ m/z 178: $\mathrm{C}_{6} \mathrm{H}_{5} \mathrm{NOCl}_{2}$<smiles>O=C1C=CC(=Nc2c(Cl)cc(O)cc2Cl)C(CC(=O)O)=C1</smiles>

$\mathrm{m} / \mathrm{z} 326: \mathrm{C}_{14} \mathrm{H}_{9} \mathrm{NO}_{4} \mathrm{Cl}_{2}$<smiles>O=C(O)Cc1cccc(O)c1</smiles>

$\mathrm{m} / \mathrm{z} 152: \mathrm{C}_{8} \mathrm{H}_{8} \mathrm{O}_{3}$<smiles></smiles>

$$
\text { m/z 296: } \mathrm{C}_{14} \mathrm{H}_{11} \mathrm{NO}_{2} \mathrm{Cl}_{2}
$$

(1) Hydroxylation

m/z 252: $\mathrm{C}_{13} \mathrm{H}_{11} \mathrm{NCl}_{2}$<smiles>O=Cc1ccccc1Nc1c(Cl)cccc1Cl</smiles>

m/z 266: $\mathrm{C}_{13} \mathrm{H}_{9} \mathrm{NOCl}_{2}$

(1)

(4)<smiles>O=CC1=CC(O)C=CC1Nc1c(Cl)cccc1Cl</smiles>

$\mathrm{m} / \mathrm{z} 282: \mathrm{C}_{13} \mathrm{H}_{9} \mathrm{NO}_{2} \mathrm{Cl}_{2}$

Scheme 1 Proposed degradation mechanism of DCF by HAP: (1) hydroxylation, (2) decarboxylation, (3) formylation (4) dehydrogenation and (5) $\mathrm{C}-\mathrm{N}$ bond cleavage. Experiment conditions: $[\mathrm{DCF}]_{0}=1 \mu \mathrm{M},[\mathrm{PS}]_{0}=50 \mu \mathrm{M}$, no buffer. 
a decarboxylation product $m / z 252\left(2-\left(2^{\prime}, 6^{\prime}\right.\right.$-dichlorphenylamino)methylbenzene). ${ }^{48}$ This product was also detected by Zhao et al. ${ }^{49}$ and Liu et al. ${ }^{50}$ in DCF degradation using ferrate(vI) and photoelectrocatalytic system, respectively.

(iii) Formylation (pathway (3) in Scheme 1) might result from the oxidation of the methyl group in the product $m / z 252$ leading to the formation of the product $m / z 266\left(2-\left(2^{\prime}, 6^{\prime}\right.\right.$-dichlorophenylamino)benzaldehyde). The product $\mathrm{m} / \mathrm{z} 282 \mathrm{might}$ be further generated from the formed $\mathrm{m} / \mathrm{z} 266$ by hydroxylation.

(iv) Dehydrogenation (pathway (4) in Scheme 1) engaged in the oxidation of the $-\mathrm{OH}$ group at $\mathrm{C} 5$ and the $-\mathrm{NH}_{2}$ group at $\mathrm{C} 2$ in the formed hydroxylation products. Zhou et al. ${ }^{51}$ reported that $-\mathrm{OH}$ and $-\mathrm{NH}_{2}$ groups in the aromatic ring are two electron-donating groups, which increased the electron density in the ortho- and para-positions of aromatic ring and therefore attracted the attacks of $\mathrm{SO}_{4}{ }^{--}$and $\mathrm{HO}^{\circ}$. As a result, two quinone imine products $\mathrm{m} / \mathrm{z} 326$ and 280 were generated from the products $\mathrm{m} / \mathrm{z} \quad 328$ and 282 through dehydrogenation, respectively.

(v) C-N bond cleavage (pathway (5) in Scheme 1) occurred between two aromatic rings of the product $m / z 328$ by the attack of reactive radicals producing two products $\mathrm{m} / \mathrm{z} 178$ and 152 . Similar transformation pathway was also reported by Chong et al. ${ }^{52}$ in the degradation of DCF using FeCeOx catalyzed $\mathrm{H}_{2} \mathrm{O}_{2}$.

\section{Conclusions}

This study systematically investigated the degradation of DCF under different experimental conditions by HAP. Compared to heat alone and PS alone systems, the degradation of DCF was significantly enhanced in HAP system at $70{ }^{\circ} \mathrm{C}$ and about $96 \%$ DCF was removed after $30 \mathrm{~min}$. Its degradation in HAP system fitted with a pseudo-first-order kinetic model. The degradation rate of DCF decreased gradually with increasing $\mathrm{pH}$ and the highest $k_{\text {obs }}$ was obtained at $\mathrm{pH} 3$ probably due to the formation of Caro's acid. The radical scavenging experiments suggested that except $\mathrm{pH} 3, \mathrm{SO}_{4}{ }^{-{ }^{-}}$was the dominant radical species at $\mathrm{pH}$ $<7$; while $\mathrm{HO}^{\circ}$ was mainly responsible for DCF degradation at high $\mathrm{pH}$ condition in HAP system. With the increase in the reaction temperature, the removal of DCF was improved, and the activation energy of this reaction was calculated to be $101.4 \mathrm{~kJ} \mathrm{~mol}^{-1}$. Increasing initial dosage of PS could enhance the elimination of DCF. Presence of $\mathrm{Cu}^{2+}$ and $\mathrm{CO}_{3}{ }^{2-}$ could improve DCF degradation, while an inhibition effect was observed in the presence of NOM. The other water constituents such as $\mathrm{Fe}^{3+}, \mathrm{SO}_{4}{ }^{2-}$ and $\mathrm{NO}_{3}{ }^{-}$could hardly influence DCF removal. Nine degradation products of DCF were detected and identified using UPLC-QTOF/MS. Hence, the probable DCF transformation mechanism was proposed showing five different reaction pathways, including hydroxylation, decarboxylation, formylation, dehydrogenation and $\mathrm{C}-\mathrm{N}$ bond cleavage.

\section{Conflicts of interest}

The authors declare no conflict of interest.

\section{Acknowledgements}

This work was supported by Sichuan Science and Technology Programs (No. 2017SZ0175 and No. 2018SZDZX0026). Yiqing Liu is also thankful to the financial support from the Fundamental Research Funds for the Central Universities (No. 2682018CX32).

\section{References}

1 A. Jelic, M. Gros, A. Ginebreda, R. Cespedes-Sánchez, F. Ventura, M. Petrovic and D. Barcelo, Water Res., 2011, 45, 1165-1176.

2 M. Carballa, F. Omil, J. M. Lema, M. Llompart, C. GarcíaJares, I. Rodríguez, M. Gómezc and T. Ternes, Water Res., 2004, 38, 2918-2926.

3 K. Fent, A. A. Weston and D. Caminada, Aquat. Toxicol., 2006, 76, 122-159.

4 N. M. Vieno, H. Harkki, T. Tuhkanen and L. Kronberg, Environ. Sci. Technol., 2007, 41, 5077-5084.

5 Y. Zhang, S. U. Geißen and C. Gal, Chemosphere, 2008, 73, 1151-1161.

6 S. K. Khetan and T. J. Collins, Chem. Rev., 2007, 107, 23192364.

7 I. S. Ruhoya and C. G. Daughton, Environ. Int., 2008, 34, 1157-1169.

8 J. L. Oaks, M. Gilbert, M. Z. Virani, R. T. Watson, C. U. Meteyer, B. A. Rideout, H. L. Shivaprasad, S. Ahmed, M. J. I. Chaudhry, M. Arshad, S. Mahmood, A. Ali and A. A. Khan, Nature, 2004, 427, 630-633.

9 J. Wang and S. Z. Wang, Chem. Eng. J., 2018, 334, 1502-1517. 10 Y. Q. Liu, X. X. He, Y. S. Fu and D. D. Dionysiou, Chem. Eng. J., 2016, 284, 1317-1327.

11 M. M. Huber, S. Canonica, G. Y. Park and U. von Gunten, Environ. Sci. Technol., 2003, 37, 1016-1024.

12 D. Vogna, R. Marotta, A. Napolitano, R. Andreozzi and M. d'lschia, Water Res., 2004, 38, 414-422.

13 M. Ravina, L. Campanella and J. Kiwi, Water Res., 2002, 36, 3553-3560.

14 L. A. Pérez-Estrada, S. Malato, W. Gernjak, A. Agüera, E. M. Thurman, I. Ferrer and A. R. Fernández-Alba, Environ. Sci. Technol., 2005, 39, 8300-8306.

15 A. Achilleos, E. Hapeshi, N. P. Xekoukoulotakis, D. Mantzavinos and D. Fatta-Kassinos, Chem. Eng. J., 2010, 161, 53-59.

16 P. Mazellier, C. Busset, A. Delmont and J. De Laat, Water Res., 2007, 41, 4585-4594.

17 F. Ghanbari and M. Moradi, Chem. Eng. J., 2017, 310, 41-62. 18 C. Q. Tan, N. Y. Gao, Y. Deng, N. An and J. Deng, Chem. Eng. J., 2012, 203, 294-300.

19 J. Deng, Y. S. Shao, N. Y. Gao, Y. Deng, S. Q. Zhou and X. H. Hu, Chem. Eng. J., 2013, 228, 765-771.

20 M. Zhang, X. Q. Chen, H. Zhou, M. Murugananthan and Y. R. Zhang, Chem. Eng. J., 2015, 264, 39-47.

21 N. Zrinyi and A. L. T. Pham, Water Res., 2017, 120, 43-51.

22 H. P. Gao, J. B. Chen, Y. L. Zhang and X. F. Zhou, Chem. Eng. J., 2016, 306, 522-530. 
23 J. B. Chen, Y. J. Qian, H. M. Liu and T. Y. Huang, Environ. Sci. Pollut. Res., 2016, 23, 3824-3833.

24 C. J. Liang, Z. S. Wang and C. J. Bruell, Chemosphere, 2007, 66, 106-113.

25 Y. Fan, D. Y. Kong, J. H. Lu and Q. S. Zhou, J. Hazard. Mater., 2015, 300, 39-47.

26 M. Spiro, Electrochim. Acta, 1979, 24, 313-314.

27 I. M. Kolthoff and I. K. Miller, J. Am. Chem. Soc., 1951, 73, 3055-3059.

28 S. Y. Yang, P. Wang, X. Yang, L. Shan, W. Y. Zhang, X. T. Shao and R. Niu, J. Hazard. Mater., 2010, 179, 552-558.

29 G. V. Buxton, C. L. Greenstock, W. P. Helman and A. B. Ross, J. Phys. Chem. Ref. Data, 1988, 17, 513-886.

30 C. L. Clifton and R. E. Huie, Int. J. Chem. Kinet., 1989, 21, 677-687.

31 P. Neta, R. E. Huie and A. B. Ross, J. Phys. Chem. Ref. Data, 1988, 17, 1027-1284.

32 Y. Q. Liu, X. X. He, Y. S. Fu and D. D. Dionysiou, J. Hazard. Mater., 2016, 305, 229-239.

33 C. Q. Tan, N. Y. Gao, Y. Deng, W. L. Rong, S. D. Zhou and N. X. Lu, Sep. Purif. Technol., 2013, 109, 122-128.

34 Y. F. Ji, C. X. Dong, D. Y. Kong, J. H. Lu and Q. S. Zhou, Chem. Eng. J., 2015, 263, 45-54.

35 A. Ghauch, A. M. Tuqan and N. Kibbi, Chem. Eng. J., 2012, 197, 483-492.

36 R. H. Waldemer, P. G. Tratnyek, R. L. Johnson and J. T. Nurmi, Environ. Sci. Technol., 2007, 41, 1010-1015.

37 G. P. Anipsitakis and D. D. Dionysiou, Environ. Sci. Technol., 2004, 38, 3705-3712.

38 C. S. Liu, K. Shih, C. X. Sun and F. Wang, Sci. Total Environ., 2012, 416, 507-512.
39 J. Deng, Y. S. Shao, N. Y. Gao, S. J. Xia, C. Q. Tan, S. Q. Zhou and X. H. Hu, Chem. Eng. J., 2013, 222, 150-158.

40 Y. Q. Liu, X. X. He, X. D. Duan, Y. S. Fu and D. D. Dionysiou, Chem. Eng. J., 2015, 276, 113-121.

41 Y. Q. Liu, X. X. He, X. D. Duan, Y. S. Fu, D. Fatta-Kassinos and D. D. Dionysiou, Water Res., 2016, 95, 195-204.

42 Y. Huang, M. B. Kong, D. Westerman, E. G. Xu, S. Coffin, K. H. Cochran, Y. Q. Liu, S. D. Richardson, D. Schlenk and D. D. Dionysiou, Environ. Sci. Technol., 2018, 52, 1269712707.

43 M. M. Ahmed, S. Barbati, P. Doumenq and S. Chiron, Chem. Eng. J., 2012, 197, 440-447.

44 J. P. Huang and S. A. Mabury, Environ. Toxicol. Chem., 2009, 19, 2181-2188.

45 P. Westerhoff, S. P. Mezyk, W. J. Cooper and D. Minakata, Environ. Sci. Technol., 2007, 41, 4640-4646.

46 P. M. D. Gara, G. N. Bosio, M. C. Gonzalez and D. O. Martire, Int. J. Chem. Kinet., 2008, 40, 19-24.

47 X. X. He, A. A. de la Cruz, K. E. O'shea and D. D. Dionysiou, Water Res., 2014, 63, 168-178.

48 V. Madhavan, H. Levanon and P. Neta, Radiat. Res., 1978, 76, 15-22.

49 J. F. Zhao, Y. Q. Liu, Q. Wang, Y. S. Fu, X. H. Lu and X. F. Bai, Sep. Purif. Technol., 2018, 192, 412-418.

50 S. S. Liu, X. Zhao, H. B. Zeng, Y. B. Wang, M. Qiao and W. Guan, Chem. Eng. J., 2017, 320, 168-177.

51 Z. W. Zhou and J. Q. Jiang, J. Pharm. Biomed. Anal., 2015, 106, 37-45.

52 S. Chong, G. M. Zhang, N. Zhang, Y. Liu, T. Huang and H. Chang, J. Hazard. Mater., 2017, 334, 150-159. 